
ISSN : 2615-1995, E-ISSN : 2615-0654

J. Madani., Vol. 1, No. 1, Maret 2018 (253-266)

(C)2018 Lembaga Kajian Demokrasi

MADANI

dan Pemberdayaan Masyarakat (LKD-PM)

\title{
ANALISIS SRATEGI BAURAN PEMASARAN (MARKETING MIX) DAN PROSPEK BISNIS PADA TOKO ONLINE " $X$ "
}

\author{
Syamruddin \\ e-mail : syamruddinbatubara@gmail.com,syam_batubara@yahoo.com \\ Dosen Program Studi Manajemen Fakultas Ekonomi \\ Universitas Pamulang, Tangerang Selatan
}

\begin{abstract}
ABSTRAK
Dewasa ini penjualan melalui saluran online sudah tidak bisa lagi terbendung. Perkembangan teknologi informasi dan komunikasi yang begitu cepat membuat kehidupan seperti tanpa batas waktu dan ruang. Saluran pemasaran yang selama ini kita kenal dengan mengutamakan tempat yang luas atau besar dengan sistem penjualan ritel mulai ditinggalkan konsumen. Akibatnya, banyak peritel yang rontok dan gulung tikar dihantam badai penjualan melalui saluran online. Analisis Strategi Bauran Pemasaran (Marketing Mix) dan Prospek Bisnis Pada Toko Online "X”, merupakan suatu tema penelitian yang sangat menarik untuk diteliti. Tujuan dari penelitian ini untuk mengetahui sampai sejauh mana strategi bauran pemasaran yang diterapkan oleh Toko Online. Begitu pula prospek bisnisnya pada masa yang akan datang. Metode penelitian yang digunakan adalah dengan melakukan pengumpulan data dalam bentuk kuesioner dan analisis data. Selain itu dilakukan pula studi pustaka. Dari sisi pemasaran, setiap perusahaan tidak luput melakukan strategi bauran pemasaran yang dalam hal ini, penulis hanya membatasi pada 4P-product, place, price, dan promotion. Dari hasil penelitian ini menunjukkan bahwa faktor bauran pemasaran sangat menentukan dalam meningkatkan penjualan. Kemudian penulis juga melakukan analisis terhadap prospek bisnis perusahaan pada masa yang akan datang.
\end{abstract}

Kata Kunci : Bauran Pemasaran/Marketing Mix (4P-Product, Price, Promotion, and Place), Prospek Bisnis.

\section{PENDAHULUAN}

\section{Latar Belakang}

Perkembangan teknologi informasi dan komunikasi yang begitu cepatnya membuat kehidupan seperti tidak ada batasnya. Begitu pula dalam membeli barang untuk keperluan seharihari. Selama ini saluran pemasaran yang selama ini kita kenal dengan penjualan ritel mulai ditinggalkan masyarakat. Keberadaan teknologi telah mengubah image masyarakat untuk ber- belanja tidak lagi harus melalui tempat-tempat yang luas dan besar seperti pasar, super market, mall, dan lain-lain. Untuk mendapatkan keperluannya sehari-hari, masyarakat cukup dengan mudah membuka alat-alat teknologi yang sudah sedemikian canggih dan memesannya melalui alat teknologi tersebut. Dalam waktu sekejap, barang yang dipesannya pun sudah diterima.

Seiring dengan semakin pesatnya pula perkembangan penjualan melalui Toko On- 
line, maka faktor persaingan pun tak dapat dihindari. Masyarakat pun semakin teliti dalam membeli dan mengambil keputusan untuk melakukan pembelian pada Toko Online. Beberapa faktor yang menjadi pertimbangan konsumen dalam melakukan pembelian adalah Bauran Pemasaran atau Marketing Mix. Dalam hal ini penulis membatasi Bauran Pemasaran pada 4P (Product, Place, Price, and Promotion).

Mengingat bahwa Bauran Pemasaran juga sangat penting dalam membeli barang pada Toko Online, maka penulis tertarik untuk melakukan penelitian lebih mendalam dengan judul: ANALISIS STRATEGI BAURAN PEMASARAN (MARKETING MIX) DAN PROSPEK BISNIS PADA TOKO ONLINE “ $X$ ”.

\section{Pembatasan Masalah}

Dengan keterbatasan yang dimiliki peneliti, sehingga lebih mudah dipahami dan dimengerti maka dalam penelitian ini penulis akan memberikan batasan-batasan yang diteliti yaitu mengenai Bauran Pemasaran/Marketing Mix (4-P; Product, Place, Price, and Promotion) dan Prospek Bisnis pada Toko Online "X".

\section{Perumusan Masalah}

Berdasarkan identifikasi dan pembatasan masalah di atas, maka untuk mencegah terjadinya kerancuan dalam pembahasan, maka penulis perlu memberikan suatu perumusan masalah sebagai berikut :

1. Bagaimana strategi bauran pemasaran yang dijalankan oleh perusahaan?

2. Bagaimana prospek bisnis Toko Online "X" ?

\section{Tujuan Penelitian}

Adapun tujuan penelitian ini adalah :

1. Mengetahui strategi pemasaran yang harus dilakukan sehingga perusahaan mempunyai prospek bisnis yang baik.

2. Memperkirakan penjualan Toko Online "X", apabila dikaitkan dengan variabel dalam bauran pemasaran, khususnya promo- si dan harga serta prospeknya pada masa yang akan datang.

\section{Tinjauan Teoritik}

\section{Pemasaran}

Pemasaran (bahasa Inggris: marketing) adalah aktivitas, serangkaian institusi, dan proses menciptakan, mengomunikasikan, menyampaikan, dan mempertukarkan tawaran yang bernilai bagi pelanggan, klien, mitra, dan masyarakat umum.

Pemasaran dimulai dengan pemenuhan kebutuhan manusia yang kemudian bertumbuh menjadi keinginan manusia. Contohnya, seorang manusia membutuhkan air dalam memenuhi kebutuhan dahaganya. Jika ada segelas air maka kebutuhan dahaganya akan terpenuhi. Namun manusia tidak hanya ingin memenuhi kebutuhannya namun juga ingin memenuhi keinginannya yaitu misalnya segelas air merek Aqua yang bersih dan mudah dibawa. Maka manusia ini memilih Aqua botol yang sesuai dengan kebutuhan dalam dahaga dan sesuai dengan keinginannya yang juga mudah dibawa.

Proses dalam pemenuhan kebutuhan dan keinginan manusia inilah yang menjadi konsep pemasaran. Mulai dari pemenuhan produk (product), penetapan harga (price), pengiriman barang (place), dan mempromosikan barang (promotion). Seseorang yang bekerja dibidang pemasaran disebut pemasar. Pemasar ini sebaiknya memiliki pengetahuan dalam konsep dan prinsip pemasaran agar kegiatan pemasaran dapat tercapai sesuai dengan kebutuhan dan keinginan manusia terutama pihak konsumen yang dituju.

\section{Strategi Pemasaran}

Strategi pemasaran merupakan hal yang sangat penting bagi perusahaan di mana strategi pemasaran merupakan suatu cara mencapai tujuan dari sebuah perusahaan, karena potensi untuk menjual proposisi terbatas pada jumlah orang yang mengetahui hal tersebut. 
Hal ini juga didukung oleh pendapat Swastha, yaitu "Strategi adalah serangkaian rancangan besar yang menggambarkan bagaimana sebuah perusahaan harus beroperasi untuk mencapai tujuannya." Sehingga dalam menjalankan usaha kecil khususnya diperlukan adanya pengembangan melalui strategi pemasarannya. Karena pada saat kondisi kritis justru usaha kecillah yang mampu memberikan pertumbuhan terhadap pendapatan masyarakat.

Pemasaran menurut W. Y. Stanton adalah sesuatu yang meliputi seluruh sistem yang berhubungan dengan tujuan untuk merencanakan dan menentukan harga sampai dengan mempromosikan dan mendistribusikan barang dan jasa yang bisa memuaskan kebutuhan pembeli aktual maupun potensial.

Berdasarkan defenisi di atas, proses pemasaran dimulai dari menemukan apa yang diinginkan oleh konsumen. Dengan demikian pemasaran memiliki tujuan yaitu :

1. Konsumen potensial mengetahui secara detail produk yang kita hasilkan dan perusahaan dapat menyediakan semua permintaan mereka atas produk yang dihasilkan.

2. Perusahaan dapat menjelaskan secara detail semua kegiatan yang berhubungan dengan pemasaran. Kegiatan pemasaran ini meliputi berbagai kegiatan, mulai dari penjelasan mengenai produk, desain produk, promosi produk, pengiklanan produk, komunikasi kepada konsumen, sampai pengiriman produk agar sampai ke tangan konsumen secara cepat.

3. Mengenal dan memahami konsumen sedemikian rupa sehingga produk cocok dengannya dan dapat terjual dengan sendirinya.

Pada umumnya kegiatan pemasaran berkaitan dengan koordinasi beberapa kegiatan bisnis. Strategi pemasaran ini dipengaruhi oleh faktor-faktor sebagai berikut :

1. Faktor mikro, yaitu perantara pemasaran, pemasok, pesaing dan masyarakat
2. Faktor makro, yaitu demografi/ekono$\mathrm{mi}$, politik/hukum, teknologi/fisik dan sosial/budaya.

Berikut ini adalah hal-hal yang perlu diperhatikan untuk pemasaran dari sudut pandang penjual :

1. Tempat yang strategis (place),

2. Produk yang bermutu (product),

3. Harga yang kompetitif (price), dan

4. Promosi yang gencar (promotion).

Sedangkan dari sudut pandang konsumen, hal-hal yang perlu diperhatikan untuk pemasaran adalah :

1. Kebutuhan dan keinginan konsumen (customer needs and wants),

2. Biaya konsumen (cost to the customer),

3. Kenyamanan (convenience), dan

4. Komunikasi (comunication).

Berdasarkan hal-hal di atas ada beberapa hal yang dapat disimpulkan, bahwa pembuatan produk atau jasa yang diinginkan oleh konsumen harus menjadi fokus kegiatan operasional maupun perencanaan suatu perusahaan. Pemasaran yang berkesinambungan harus adanya koordinasi yang baik dengan berbagai departemen (tidak hanya di bagian pemasaran saja), sehingga dapat menciptakan sinergi di dalam upaya melakukan kegiatan pemasaran.

\section{Bauran Pemasaran}

Bauran pemasaran secara umum adalah kumpulan dari variabel-variabel pemasaran yang dapat dikendalikan dan digunakan oleh suatu badan usaha untuk mencapai tujuan pemasaran dalam pasar sasaran. Menurut Kotler (2009), bauran pemasaran adalah sejumlah alat-alat pemasaran yang digunakan perusahaan untuk meyakinkan obyek pemasaran atau target pasar yang dituju. Mc Carthy dalam Kotler dan Keller (2009) mengklasifikasikan Bauran Pemasaran (Marketing Mix) menjadi empat besar kelompok yang disebut dengan $4 \mathrm{P}$ tentang pemasaran yaitu Product (produk), Price (harga), Place (tempat/distribusi) dan Promotion (promosi). 
Sedangkan menurut Stanton (2000), Bauran Pemasaran (Marketing Mix) adalah kombinasi dari empat variabel atau kegiatan yang merupakan inti dari sistem pemasaran perusahaan yaitu produk, harga, kegiatan promosi, dan sistem distribusi.

Dalam perkembangannya, bauran pemasaran yang terdiri dari $4 \mathrm{P}$ terus berkembang, yaitu menjadi $7 \mathrm{P}$ yang meliputi product, price, place, promotion, process, people, dan physical evidence. Selanjutnya berkembang menjadi 8P yakni product, price, place, promotion, process, people, physical evidence, dan productivity.

Menurut Morissan dalam Dewi (2011) menyatakan bahwa konsep Marketing Mix diperluas menjadi 8P, dengan penambahan People, Packaging, Partnership, dan Programming. Jadi Bauran Pemasaran (Marketing Mix) secara keseluruhan terdiri dari 8P, yaitu :

\section{Product (produk).}

Menurut Kotler dan Keller (2009), produk adalah segala sesuatu yang dapat ditawarkan ke pasar untuk memenuhi kebutuhan dan keinginan konsumen. Keputusan tentang produk ini mencakup penentuan bentuk penawaran secara fisik, merk-nya, pembungkus, garansi dan servis sesudah penjualan. Pengembangan produk dapat dilakukan setelah menganalisa kebutuhan dan keinginan pasarnya. Jika masalah ini telah diselesaikannya, maka keputusan-keputusan tentang harga, distribusi, dan promosi dapat diambil.

\section{Price (Harga)}

Menurut Kotler dan Keller (2009), harga adalah elemen dalam bauran pemasaran yang tidak saja menentukan profitabilitas tetapi juga sebagai sinyal untuk mengkomunikasikan proporsi nilai suatu produk. Pemasaran produk perlu memahami aspek psikologis dari informasi harga yang meliputi harga referensi (reference price), inferensi kualitas berdasarkan harga (price- quality inferences) dan petunjuk harga (price clues). Pada setiap produk atau jasa yang ditawarkan, bagian pemasaran berhak menentukan harga pokoknya. Faktorfaktor yang perlu dipertimbangkan dalam penetapan harga tersebut antara lain biaya, keuntungan, praktik saingan, dan perubahan keinginan pasar. Kebijaksanaan harga ini menyangkut pula penetapan jumlah potongan, mark-up, mark-down, dan sebagainya.

\section{Place (Distribusi)}

Ada tiga aspek pokok yang berkaitan dengan keputusan-keputusan tentang distribusi (tempat). Aspek-aspek tersebut adalah :

- Sistem transportasi perusahaan; termasuk dalam sistem ini antara lain keputusan tentang pemilihan alat transportasi (pesawat udara, kereta api, kapal, truk, pipa), penetuan jadwal pengiriman, penentuan rute yang harus ditempuh dan seterusnya.

- Sistem penyimpanan; dalam sistem ini bagian pemasaran harus menentukan letak gudang, jenis peralatan yang dipakai untuk menangani material maupun peralatan lainnya.

- Pemilihan saluran distribusi; menyangkut keputusan-keputusan tentang penggunaan penyalur (pedagang besar, pengecer, agen, makelar), dan bagaimana menjalin kerja sama yang baik dengan para penyalur tersebut.

\section{Promotion (Promosi)}

Menurut Kotler dan Keller (2009), promosi adalah berbagai cara untuk menginformasikan, membujuk, dan mengingatkan konsumen secara langsung maupun tidak langsung tentang suatu produk atau brand yang dijual. 


\section{People (Orang-Orang)}

Menurut Dewi (2011), people merupakan penyedia barang dan jasa yang melayani konsumen. People sedikitnya memiliki tiga hal yaitu service personnel, the product themselves, dan local resident. Dalam hal ini pelatihan, pengendalian kualitas, standardisasi kualifikasi, dan sertifikasi kompetensi menjadi bagian yang penting dalam menentukan keberhasilan suatu pemasaran.

\section{Packaging (Kemasan)}

Menurut Morissan (2010), packaging berarti pengelompokan dua elemen atau lebih dari product experience ke dalam suatu produk. Packaging adalah kombinasi dari jasa dan daya tarik produk yang saling berkaitan dalam satu paket penawaran harga. Serangkaian produk yang dikemas dan dijual dengan menarik akan membentuk pengalaman yang menarik pula.

\section{Programming (Program)}

Menurut Morissan (2010), programming adalah suatu teknik yang berkaitan dengan packaging, yaitu pengembangan aktivitas tertentu, acara, atau program untuk menarik dan meningkatkan pembelanjaan, atau memberikan nilai tambah pada paket atau produk. Packaging memiliki kaitan dengan packaging yang melibatkan event special aktivitas atau program suatu produk untuk membuatnya lebih beraneka ragam dan menarik.

\section{Partnership (Kerja Sama)}

Suatu hubungan yang dijalin dengan usaha yang sejenis maupun usaha tidak sejenis yang menciptakan benefit dari pihakpihak tersebut.

Namun dalam penelitian ini, penulis hanya membatasi Bauran Pemasaran (Marketing Mix) pada empat aspek, yaitu produk, price, place, dan promotion. Adapun pengertian lain dari keempat bauran pemasaran tersebut secara singkat dapat dijelaskan pula sebagai berikut:

1. Product (produk) adalah segala sesuatu yang ditawarkan kepada masyarakat untuk dilihat, dipegang, dibeli atau di konsumsi. Produk dapat terdiri dari product variety, quality, design, feature, brand name, packaging, sizes, services, warranties, and returns.

2. Price (harga), yaitu sejumlah uang yang konsumen bayar untuk membeli produk atau mengganti hal milik produk. Harga meliputi last price, discount, allowance, payment period, credit terms, and retail price.

3. Promotion (promosi), yaitu berbagai kegiatan perusahaan untuk mengkomunikasikan dan memperkenalkan produk pada pasar sasaran. Variabel promosi meliputi antara lain sales promotion, advertising, sales force, public relation, and direct marketing.

4. Place (tempat), yaitu berbagai kegiatan perusahaan untuk membuat produk yang dihasilkan/dijual terjangkau dan tersedia bagi pasar sasaran. Tempat meliputi antara lain channels, coverage, assortments, locations, inventory, and transport.

\section{Segmenting, Targeting, dan Positioning}

Bagaimanapun juga, para penjual atau para pemasar tidak bisa lepas dari suatu metode pemasaran modern yang berdasarkan pada segmentasi, target, dan posisi. Suatu organisasi yang beroperasi dalam suatu pasar, apakah itu pasar konsumsi, pasar penyalur atau pasar pemerintah selalu menyadari bahwa pada hakekatnya ia tidak dapat melayani seluruh pelanggan dalam pasar tersebut. Pelanggan terlalu banyak, sangat berpencar beraneka ragam dalam tuntutan penjualannya. Mungkin beberapa pesaing memiliki posisi yang lebih baik dan le- 
bih kuat untuk melayani beberapa segmen pasar tertentu sedangkan perusahaan sendiri dari pada bersaing di mana saja, lebih baik menetapkan bagian mana yang paling menarik untuk dimasuki secara efektif.

Jantung pemasaran strategis modern dapat dijelaskan sebagai pemasaran STP yang merupakan kependekan dari Segmenting, Targeting, dan Positioning. Ketiga langkah ini dapat dijelaskan sebagai berikut :

1. Segmentasi pasar (Segmenting), yaitu tindakan membagi suatu pasar menjadi kelompok-kelompok pembeli yang berbeda-beda yang mungkin membutuhkan produk-produk dan atau kombinasi pemasaran yang terpisah.

2. Penentuan pasar sasaran (Targeting), yaitu suatu tindakan mengevaluasi keaktifan daya tarik setiap segmen pasar dan memilih salah satu atau lebih dari segmen pasar tersebut untuk dimasuki.

3. Penempatan produk (Positioning), yaitu tindakan untuk menempatkan posisi bersaing produk dan Bauran Pemasaran yang tepat pada setiap pasar sasaran.

Menurut Kotler dan Armstrong (2008), Segmentasi Pasar (Marketing Segmentation) didefenisikan sebagai pembagian pasar menjadi kelompok-kelompok yang lebih kecil berdasarkan kebutuhan, karakteristik, atau sifat yang membutuhkan produk dan strategi pemasaran masing-masing secara berbeda satu sama lain.

Beberapa tipe segmentasi pasar menurut Kotler dan Armstrong (2008), yaitu :

- Geografi (Geographic), sebagai contoh: negara, kota benua.

- Demografi (Demographic), sebagai contoh : umur, jenis kelamin, pendapatan.

- Psikografi (Psychographic), sebagai contoh : kelas sosial, gaya hidup.

- Sifat (Behavioral), sebagai contoh : skala penggunaan produk, keuntungan yang diinginkan dari produk, kesetiaan (loyalty) terhadap produk.
Selanjutnya, defenisi Targeting menurut Keegan dan Green (2008), adalah proses pengevaluasian segmentasi dan pemfokusan strategi pemasaran pada sebuah negara, provinsi atau sekelompok orang yang memiliki potensi untuk memberikan respon. Sedangkan defenisi target pasar (market target) menurut Kotler dan Armstrong (2008) adalah sekelompok pembeli (buyers) yang memiliki kebutuhan atau karakteristik yang sama yang menjadi tujuan dari promosi perusahaan.

Dari kedua defenisi tersebut di atas, Targeting merupakan sebuah proses yang sangat penting karena akan menentukan siapa yang akan membeli produk dari perusahaan. Segmentasi dari target market dapat dibagi menjadi empat macam, di mana menurut Kotler dan Armstrong (2008), sebagai berikut :

- Undifferentiated (Mass) Marketing

- Differentiated (Segmented) Marketing

- Concentrated (Niche) Marketing

- Micromarketing (Local atau Individual) Marketing

Sementara itu defenisi Positioning menurut Kotler \& Keller (2009) adalah suatu usaha perusahaan untuk memberikan gambaran (image) di dalam pikiran konsumen ketika melihat atau mendengar tentang produk atau brand dari perusahaan tersebut. Tujuan akhir dari Positioning adalah terbentuknya suatu proporsi nilai (value) sebuah produk pada seorang konsumen yang menciptakan suatu alasan meyakinkan mengapa mereka harus membeli produk tersebut.

\section{Belanja Daring}

Belanja Online atau biasa dikenal dengan Toko Online atau Online Shop merupakan tempat pembelian barang dan jasa melalui media internet. Belanja Online atau Toko Online adalah salah satu bentuk perdagangan elektronik (Ecommerce) digunakan untuk kegiatan transaksi penjual ke penjual ataupun penjual ke konsumen.

Dalam istilah lain, Belanja Online atau yang lebih familiar pula disebut Belanja Daring adalah kegiatan pembelian barang dan jasa melalui 
media internet. Melalui belanja lewat internet seorang pembeli bisa melihat terlebih dahulu barang dan jasa yang hendak ia belanjakan melalui web yang dipromosikan oleh penjual.

Kegiatan Belanja Daring ini merupakan bentuk komunikasi baru yang tidak memerlukan komunikasi tatap muka secara langsung, melainkan dapat dilakukan secara terpisah dari dan ke seluruh dunia melalui media notebook, komputer, ataupun handphone yang tersambung dengan layanan akses internet. Belanja Daring adalah salah satu bentuk perdagangan elektronik yang digunakan untuk kegiatan transaksi penjual ke penjual ataupun penjual ke konsumen.

Belanja Online (Belanja Daring) adalah suatu bentuk perdagangan menggunakan perangkat elektronik yang memungkinkan konsumen untuk membeli barang atau jasa dari penjual melalui internet. Nama lain kegiatan tersebut adalah: $e$-web-shop, e-shop, e-toko, toko internet, web-shop, web-store, toko online, toko online, dan toko virtual.

Sebuah Toko Online membangkitkan pembelian produk atau jasa pada pengecer atau pusat perbelanjaan yang Kini disebut dengan istilah Belanja Online Business-to-Consumer (B2C). Dalam proses lain di mana bisnis membeli dari bisnis lain, disebut Belanja Online Business-toBusiness (B2B).

Saat ini Belanja Online sudah semakin canggih dengan adanya perdagangan via ponsel (m-commerce). Telepon seluler telah dioptimalkan dengan sebuah aplikasi untuk membeli dari situs online.

Kesuksesan sebuah ritel tidak lagi semua tentang fisik bangunan, ini terbukti dengan peningkatan pengecer yang menawarkan antarmuka Toko Online bagi konsumen. Dengan pertumbuhan Belanja Online, banyak peluang pasar baru untuk toko memenuhi permintaan pasar luar negeri dengan persyaratan layanan tertentu. Contoh perusahaan ritel online terbesar adalah Alibaba, Amazon.com, eBay, Granton World, dan lain-lain.
Dalam perkembangannya, Belanja Online (belanja daring) semakin terus meningkat. Server World Wide Web (WWW) dan Browser, yang dibuat oleh Tim Berners-Lee pada tahun 1990, dibuka untuk penggunaan komersial pada tahun 1991. Iinovasi teknologi berikutnya muncul pada tahun 1994 dengan munculnya Netscape's SSL standar enkripsi v2 untuk keamanan transfer data dibuat, maka online banking diterapkan. Dan, Intershop pertama kali memakai sistem Belanja Online. Tidak ketinggalan Pizza Hut membuka toko pizza online. Setelah itu Amazon.com dan eBay meluncurkan situs Belanja Online di tahun 1995.

Bahkan dalam sebuah survei yang dilakukan oleh ShopBack Indonesia, menunjukkan bahwa membeli perlengkapan di Toko Daring atau Toko Online dianggap lebih efisien terutama di tengah kondisi cuaca yang kurang bersahabat. Dalam beberapa tahun belakang, memang semakin banyak masyarakat melakukan transaksi di Toko Daring. Masyarakat yang berbelanja melalui Toko Online dan Toko Offline tidak terlalu menunjukkan perbedaan signifikan. Hal ini membuktikan, saat ini kepercayaan masyarakat untuk berbelanja online semakin meningkat. Padahal dua sampai tiga tahun lalu, masyarakat masih enggan untuk menghabiskan banyak uang untuk berbelanja daring. Hal ini disebabkan tingkat kepercayaan serta keamanan dalam bertransaksi daring masih terbilang rendah pada saat itu.

\section{Toko Online}

Pengertian Toko Online adalah sarana atau toko untuk menawarkan barang dan jasa lewat internet, di mana pengunjung dapat melihat barang-barang Anda di Toko Online Anda, berupa foto-foto.

Definisi bisnis online sering kali diasumsikan oleh internet marketer bahwa semua bisnis yang dilakukan secara online dengan menggunakan media internet sebagai media pemasaran produk dan jasa adalah mencakup bagianbagian dari bisnis online 
Beberapa keuntungan Toko Online dibanding Toko offline. Pertama keuntunganya tentu sangat banyak, di samping pengunjung yang datang adalah yang betul-betul berminat dengan produk Anda, maka Anda juga tidak perlu dibuat repot membuat pamflet ataupun membuat iklan-iklan di media offline.

Kedua, Toko Online tidak harus ditungguin, bahkan Anda tinggal menerima order jika ada pelanggan yang berminat dengan produk Anda. Dan, ketiga sarana paling efektif untuk promosi di zaman kemajuan tekhnologi. Karena saat ini internet dapat diakses dimanapun, bahkan lewat handphone.

Kelebihan bisnis online, di antaranya adalah :

1. Tidak terikat waktu dan tempat.

2. Pangsa pasar yang luas.

3. Media promosi yang efektif.

4. Modal dan biaya operasional yang relatif.

\section{Prospek Bisnis}

Prospek bisnis adalah kondisi yang akan dihadapi oleh perusahaan pelaku usaha di masa yang akan datang dilihat dari potensi dan berbagai faktor pendorong dan penghambatnya sehingga terlihat seberapa besar peluang keuntungan yang mungkin terjadi atau bisa juga sebaliknya seberapa besar kerugian yang mungkin terjadi. Prospek bisnis suatu usaha akan menunjukan kecenderungan untuk meningkat atau menutup. Kondisi ini dipengaruhi oleh berbagai peluang dan ancaman yang dihadapi. Kelemahan dan kekuatan yang dimiliki pelaku usaha/entrepreneur perusahaan sehingga diperlukan perencanaan dan perumusan strategis perusahaan secara baik.

\section{Hipotesis Penelitian}

Hipotesis menurut Sugiyono (2012:64) adalah pernyataan singkat yang merupakan jawaban sementara terhadap masalah yang diteliti serta masih perlu diuji kebenarannya. Karena sifatnya masih sementara, maka perlu dibuktikan kebenarannya melalui data empirik yang terkumpul.
Hipotesis merupakan jawaban sementara terhadap perumusan masalah. Karena masih bersifat sementara, maka perlu dibuktikan kebenarannya melalui data-data empirik yang dikumpulkan.

Adapun hipotesis yang penulis ajukan adalah sebagai berikut :

1. Terdapat hubungan positif dan signifikan antara penjualan dengan variabel-variabel Bauran Pemasaran (4-P).

2. Penerapan strategi pemasaran yang tepat akan dapat membantu perusahaan dalam meningkatkan penjualan.

3. Apabila permintaan lebih besar daripada penawaran, maka prospek bisnis perusahaan akan lebih baik.

\section{METODOLOGI PENELITIAN \\ Tempat dan Waktu Penelitian}

Penulis mengadakan penelitian pada Toko Online "X" di Jabodetabek. Adapun penelitian ini dilaksanakan pada bulan Oktober 2017 sampai dengan Januari 2018.

\section{Populasi dan Sampel}

Adapun populasi dalam penelitian ini adalah para konsumen muda yang usianya berkisar antara 20 - 35 tahun. Jumlah sampel yang diambil sebanyak 100 orang konsumen.

\section{Variabel Penelitian}

Dalam penelitian ini ada dua variabel yaitu independen dan dependen, sebagai berikut :

1. Variabel independen (bebas) yang dalam hubungannya dengan variabel lain bertindak sebagai penyebab atau yang mempengaruhi variabel dependen. Dalam penelitian ini variabel independen adalah strategi bauran pemasaran dan prospek bisnis.

2. Variabel dependen (terikat) yaitu variabel yang tergantung dengan variabel lain atau variabel yang dapat dipengaruhi oleh variabel lain. Dalam penelitian ini variabel dependen adalah hasil yang dicapai oleh Toko Online " $\mathrm{X}$ ". 


\section{Defenisi Operasional Variabel}

Pengertian operasional variabel ini diuraikan menjadi indikator empiris yang meliputi :

1. Strategi Bauran Pemasaran (X1)

Variabel ini diukur melalui indikator Bauran Pemasaran (4-P).

2. Prospek Bisnis (X2)

Variabel ini diukur melalui permintaan, penawaran, dan penjualan.

3. Hasil yang dicapai

Variabel ini diukur melalui indikator hasil pencapaian yang diperoleh apabila dalam bisnisnya menggunakan Strategi Bauran Pemasaran dan melakukan penilaian terhadap permintaan, penawaran, dan penjualan.

\section{Metode Pengumpulan Data}

Metode yang digunakan dalam penelitian ini adalah metode deskriptif. Tujuannya agar dapat diperoleh fakta yang melukiskan gambaran sebenarnya sehingga dapat dianalisa. Teknik pengumpulan data dilakukan dengan cara menyebarkan kuesioner dan riset kepustakaan.

\section{Metode Analisis Data}

Sedangkan metode analisis data adalah dengan menggunakan indikasi variabel dan model.

1. Indikasi Variabel

Penilaian faktor-faktor internal didasarkan pada kekuatan relatif faktor-faktor tersebut terhadap pesaing dekatnya. Sedangkan penilaian terhadap faktor-faktor eksternal diukur dari daya tarik industri atau pasar di mana perusahaan tersebut beroperasi.

\section{Model}

Model yang dipakai dalam studi ini adalah persamaan fungsional yaitu :

$\mathrm{Y}=\mathrm{f}(\mathrm{X} 1, \mathrm{X} 2, \mathrm{X} 3$,

Di mana $\mathrm{Y}$ mempunyai hubungan linear dengan X1, X2, X3, .............. Xn, sehingga model persamaan tersebut menjadi :

$\mathrm{Y}=\mathrm{a}+\mathrm{b} 1 \mathrm{X} 1+\mathrm{b} 2 \mathrm{X} 2+\mathrm{b} 3 \mathrm{X} 3+\ldots \ldots . . \mathrm{bnXn}$

Supranto (1993) menyatakan bahwa kore- lasi pada dasarnya adalah hubungan. Dua kejadian yang berhubungan, apabila ingin diukur kuat tidaknya hubungan tersebut, maka kejadian tersebut harus dinyatakan dalam nilai variabel. Misalnya : hubungan antara variabel $\mathrm{X}$ dengan $\mathrm{Y}$. Oleh karena itu perubahan $\mathrm{X}$ akan mempengaruhi Y.

Aplikasi dari persamaan di atas pada penelitian ini adalah :

Model yang dipakai untuk mengukur volume penjualan jika dikaitkan dengan promosi dan harga adalah :

$$
\begin{aligned}
& \mathrm{Y}=\mathrm{a}+\mathrm{b} 1 \mathrm{X} 1+\mathrm{b} 2 \mathrm{X} 2 \\
& \mathrm{Di} \text { mana : } \\
& \mathrm{Y} \quad=\text { jumlah penjualan } \\
& \mathrm{a} \quad=\text { konstanta } \\
& \mathrm{b} 1, \mathrm{~b} 2 \quad=\text { koefisien dari variabel terkait } \\
& \mathrm{X} 1 \quad=\text { harga Toko Online "X" } \\
& \mathrm{X} 2 \quad=\text { biaya promosi }
\end{aligned}
$$

Sementara itu model yang digunakan untuk memprediksi jumlah permintaan dan penawaran terhadap suatu produk barang pada masa yang akan datang.

Fungsi permintaan dapat dirumuskan sebagai berikut :

$$
\mathrm{Qd}=\mathrm{f}(\mathrm{P} \text { HEN , I ) }
$$

Sedang bentuk persamaan regresi linearnya adalah :

$\mathrm{Qd}=\mathrm{a}+\mathrm{b} 1 \mathrm{pHEN}+\mathrm{b} 2 \mathrm{I}$

Di mana :

Qd = jumlah permintaan Toko Online

a $\quad=$ konstanta

b1, b2 = koefisien dari variabel terkait

pHEN $=$ harga Toko Online di tingkat konsumen

I = pendapatan penduduk per jiwa

Fungsi penawaran dapat dirumuskan sebagai berikut :

$\mathrm{Qs}=\mathrm{f}(\mathrm{PEN}, \mathrm{pK})$

Adapun untuk bentuk persamaan regresi linearnya adalah sebagai berikut :

$\mathrm{Q} s=\mathrm{a}+\mathrm{b} 1 \mathrm{p} \mathrm{HEN}+\mathrm{b} 2 \mathrm{pK}$

Di mana :

Qs = jumlah penawaran Toko Online

a $\quad$ konstanta 
b1 , b2 = koefisien dari variabel terkait

pHEN = harga Toko Online di tingkat konsumen

$\mathrm{pK}=$ harga barang di tingkat pedagang/produsen

\section{HASIL PENELITIAN dan PEMBAHASAN Hasil Penelitian}

Secara umum perkembangan penjualan Toko Online "X" mengalami fluktuasi. Dari hasil studi yang dilakukan rata-rata per hari selama periode Oktober 2017 sampai dengan Januari 2018 sebagaimana tergambar dalam tabel berikut :

\section{Tabel 1}

Penjualan Toko Online "X"

$$
\text { Rata-rata per Hari }
$$

Periode Oktober 2017 - Januari 2018

\begin{tabular}{|c|c|}
\hline Bulan/Tahun & Penjualan (Rp./Juta) \\
\hline Oktober 2017 & 10 \\
\hline November 2017 & 9,5 \\
\hline Desember 2017 & 9,0 \\
\hline Januari 2018 & 11 \\
\hline
\end{tabular}

Sumber : Hasil Studi

\section{Pembahasan}

\section{Strategi Bauran Pemasaran}

Dalam Strategi Bauran Pemasaran, analisis yang dilakukan adalah melalui pendekatan teori general electric matriks, di mana kekuatan internal (business strength) dan kekuatan eksternal (industry attractiveness). Bobot yang digunakan dalam metode ini adalah sebagai berikut :

\begin{tabular}{|c|c|}
\hline High (H) & 3 \\
\hline Medium (M) & 2 \\
\hline Low (L) & 1 \\
\hline
\end{tabular}

Berdasarkan hasil pembahasan menunjukkan bahwa penilaian terhadap Strategi Bauran Pemasaran sebagai berikut :
Tabel 1.1

Penelitian Bauran Pemasaran (Produk) Pada 100 Responden

Periode Oktober 2017 s/d Januari 2018

\begin{tabular}{|ll|c|}
\hline \multicolumn{2}{|c|}{ Variabel-variabel } & Bobot \\
\hline 1. & Keragaman produknya & 2 \\
2. & Kualitasnya terjamin & 2 \\
3. & Desain produknya yang bagus dan menarik & 2 \\
4. & Ciri produknya yang lebih jelas & 3 \\
5. & Nama mereknya dikenal & 2 \\
6. & Kemasan dan ukurannya baik & 2 \\
7. & Pelayanannya yang bagus & 3 \\
8. & Adanya garansi dan imbalan & 2 \\
\hline \multicolumn{2}{|c|}{ Nilai Rata-rata } & $\mathbf{2 , 2 5}$ \\
\hline
\end{tabular}

Sumber : Hasil Studi

Tabel 1.2

Penelitian Bauran Pemasaran (Harga) Pada 100 Responden

Periode Oktober 2017 s/d Januari 2018

\begin{tabular}{|ll|c|}
\hline \multicolumn{2}{|c|}{ Variabel-variabel } & Bobot \\
\hline 1. & Daftar harga yang bervariasi dan jelas & 2 \\
2. & Potongan harga khusus & 2 \\
3. & Adanya syarat kredit yang mudah & 2 \\
4. & Adanya diskon/rabat & 2 \\
5. & Periode pembayaran yang lunak & 2 \\
\hline \multicolumn{2}{|c|}{ Nilai Rata-rata } & $\mathbf{2 , 0 0}$ \\
\hline
\end{tabular}

Sumber : Hasil Studi

Tabel 1.3

\section{Penelitian Bauran Pemasaran (Promosi) Pada 100 Responden}

Periode Oktober 2017 s/d Januari 2018

\begin{tabular}{|c|c|}
\hline Variabel-variabel & Bobot \\
\hline 1. Promosi penjualan yang kontinyu & 3 \\
\hline 2. Periklanannya yang menarik & 3 \\
\hline 3. Tenaga penjualannya yang ramah & 2 \\
\hline 4. Kehumasan atau public relation-nya & 2 \\
\hline 5. Pemasaran langsungnya & 3 \\
\hline Nilai Rata-rata & 2,6 \\
\hline
\end{tabular}

Sumber : Hasil Studi 
Tabel 1.4

Penelitian Bauran Pemasaran (Tempat/Distribusi) Pada 100 Responden

Periode Oktober 2017 s/d Januari 2018

\begin{tabular}{|ll|c|}
\hline \multicolumn{2}{|c|}{ Variabel-variabel } & Bobot \\
\hline 1. Karena saluran pemasarannya & 2 \\
2. & Cakupan pasarnya yang luas & 2 \\
3. Pengelompokan barangnya yang mudah & \\
dicari & 3 \\
4. Lokasinya yang mudah diakses & 2 \\
5. Persediaan barangnya yang banyak & 3 \\
6. Transportasi yang tidak sulit & 2 \\
\hline \multicolumn{2}{|c|}{ Nilai Rata-rata } & $\mathbf{2 , 3}$ \\
\hline
\end{tabular}

Sumber : Hasil Studi

Tabel 1.5

Penelitian Bauran Pemasaran Pada 100 Responden

Periode Oktober 2017 s/d Januari 2018

\begin{tabular}{|ll|c|}
\multicolumn{1}{|c|}{ Variabel-variabel } & Bobot \\
\hline 1. & Produk & 2,25 \\
2. Harga & 2,00 \\
3. Promosi & 2,60 \\
4. Tempat/Distribusi & 2,30 \\
\hline \multicolumn{2}{|c|}{ Nilai Rata-rata } & $\mathbf{2 , 2 9}$ \\
\hline
\end{tabular}

Sumber : Hasil Studi

\section{Prospek Bisnis Toko Online " $X$ "}

Adapun prospek bisnis Toko Online " $\mathrm{X}$ " pada masa yang akan datang berdasarkan prakiraan penjualan, permintaan, dan penawaran dapat diketahui pada tabel-tabel di bawah ini.

Tabel 2.1

Prakiraan Penjualan Toko Online " $\mathrm{X}$ "

Rata-rata per hari Februari - April 2018

\begin{tabular}{|c|c|}
\hline Bulan/Tahun & Penjualan (Rp./Juta) \\
\hline Februari 2018 & 14,01 \\
\hline Maret 2018 & 14,04 \\
\hline April 2018 & 14,08 \\
\hline
\end{tabular}

Sumber : Hasil olahan dari persamaan regresi dengan asumsi kenaikan biaya promosi $25 \%$ per bulan.

Apabila biaya promosi dinaikkan, maka penjualan akan meningkat. Dengan demikian bauran promosi perlu lebih dilakukan peningkatannya.
Tabel 2.2

Prakiraan Permintaan Toko Online " $X$ "

Rata-rata per hari Februari - April 2018

\begin{tabular}{|c|c|}
\hline Bulan/Tahun & Penjualan (Rp./Juta) \\
\hline Februari 2018 & 19 \\
\hline Maret 2018 & 17 \\
\hline April 2018 & 14 \\
\hline
\end{tabular}

Sumber : Hasil olahan dari persamaan regresi dengan asumsi kenaikan harga 10\% per tiga bulan.

Terjadinya penurunan terhadap permintaan apabila harga dinaikkan setiap tiga bulan perlu dikendalikan dengan sebaik-baiknya sehingga permintaan terhadap Toko Online " $\mathrm{X}$ " dapat mengalami kenaikan.

Tabel 2.3

Prakiraan Penawaran Toko Online " $\mathrm{X}$ "

Rata-rata per hari Februari - April 2018

\begin{tabular}{|c|c|}
\hline Bulan/Tahun & Penjualan (Rp./Juta) \\
\hline Februari 2018 & 21 \\
\hline Maret 2018 & 19 \\
\hline April 2018 & 18 \\
\hline
\end{tabular}

Sumber : Hasil olahan dari persamaan regresi dengan asumsi kenaikan harga 10\% per tiga bulan.

Perkiraan penawaran mengalami penurunan, apabila harga dinaikkan setiap tiga bulan. Dengan kondisi seperti ini, sebaiknya perusahaan mulai berhati-hati dan mencari strategi baru agar tetap dapat bertahan. Karena tidak mungkin bisa dielakkan adanya kenaikan harga produk yang diakibatkan meningkatnya biayabiaya yang yang harus dikeluarkan.

Dari tabel-tabel di atas, maka dapat diketahui perkiraan bisnis Toko Online " $\mathrm{X}$ " adalah sebagai berikut :

Tabel 2.4

Perkiraan Bisnis Toko Online " $\mathrm{X}$ "

Rata-rata per hari Februari - April 2018

\begin{tabular}{|l|c|c|c|}
\multicolumn{1}{|c|}{ Tahun } & $\begin{array}{c}\text { Jumlah Permintaan } \\
\text { (Rp./Juta) }\end{array}$ & $\begin{array}{c}\text { Jumlah Penawaran } \\
\text { (Rp./Juta) }\end{array}$ & Hasil \\
\hline Februari $\mathbf{2 0 1 8}$ & 19 & 21 & D < S \\
\hline Maret 2018 & 17 & 19 & D < S \\
\hline April 2018 & 14 & 18 & D $<$ S \\
\hline
\end{tabular}


Berdasarkan tabel di atas dapat dijelaskan bahwa untuk meningkatkan volume penjualannya manajemen harus melakukan strategi baru. Strategi diferensiasi dapat dilakukan untuk meningkatkan kualitas, citra, distribusi, dan inovasi. Agar dapat bersaing dan mencapai keunggulan, suatu perusahaan harus memiliki produk yang berkualitas. Manajemen harus membuat sesuatu yang berbeda atau lebih baik dari para pesaing melalui rancangan produk, promosi, harga, dan sebagainya.

\section{KESIMPULAN dan SARAN \\ Kesimpulan}

Dari berbagai uraian di atas dapat disimpulkan beberapa hal penting sebagai berikut :

1. Strategi Bauran Pemasaran sudah baik karena mengingat dari hasil penelitian menunjukkan bahwa kondisi saat ini berada di atas menengah/netral yaitu dengan bobot nilai 2,29.

2. Keempat Bauran Pemasaran sudah cukup dijabarkan kepada inti pemasaran strategis modern yaitu Segmentasi, Targeting, dan Positioning (STP).

3. Dari sisi prospek bisnis, kondisi perusahaan masih cukup baik. Kendati jumlah permintaan masih lebih kecil dari jumlah penawaran, namun secara umum marjinnya masih tidak terlalu besar. Hal itu tampak dari jumlah permintaan yang tidak jauh dari jumlah penawaran, sehingga menunjukkan bahwa perusahaan masih cukup representatif untuk terus mengelola bisnisnya.

\section{Saran}

Berdasarkan hasil penelitian dan pembahasan yang diperoleh serta kesimpulan, penulis mengajukan saran-saran sebagai berikut :

1. Implementasi Strategi Bauran Pemasaran perlu ditingkatkan lagi mengingat fenomena bisnis online semakin hari semakin berkembang.
2. Manajemen perlu melakukan diferensiasi bisnis untuk dapat terus menggenjot penjualan yang sudah cukup baik.

3. Kendati jumlah permintaan yang tidak begitu jauh dari jumlah penawaran, namun perbedaan ini tetap harus menjadi perhatian yang serius dari manajemen.

4. Perusahaan perlu lebih fokus pada aspek harga dan promosi agar bisa biasa bersaing dengan Toko Online yang lain.

\section{DAFTAR PUSTAKA}

Assauri, Sofjan. 2007. "Manajemen Pemasaran, Dasar, Konsep dan Strategi”, Penerbit PT Raja Grafindo Persada. Jakarta.

Dewi, Ike Janita. 2011. "Pemasaran Pariwisata Yang Bertanggung Jawab", Penerbit Kementerian Kebudayaan dan Pariwisata Republik Indonesia. Jakarta.

Keegan, Warren J., dan Mark C. Green. 2008. "Global Marketing", Penerbit Pearson Education. London.

Kotler, Philip dan Gary Armstrong. 2009. "Manajemen Pemasaran", Edisi Ketigabelas, Penerbit Erlangga. Jakarta.

Kotler, Philip dan Gary Armstrong. 2012. "Prinsip-prinsip Pemasaran", Edisi Ketigabelas, Jilid 1, Penerbit Erlangga. Jakarta.

Kotler, Philip dan Gary Armstrong. 2012." Prinsip-prinsip Pemasaran", Edisi Ketigabelas, Jilid 2, Penerbit Erlangga. Jakarta.

Kotler, Philip dan Kevin Lane Keller. 2009. "Manajemen Pemasaran", Edisi Ketigabelas, Jilid 1, Penerbit Erlangga. Jakarta.

Kotler, Philip dan Kevin Lane Keller. 2009. "Manajemen Pemasaran", Edisi Ketigabelas, Jilid 2, Penerbit Erlangga. Jakarta.

Kuncoro, Mudrajad, "Metode Riset untuk Bisnis \& Ekonomi”. 2014. Edisi 4, Penerbit Erlangga. Jakarta.

Laksana, Fajar. 2013. "Manajemen Pemasaran", Edisi Pertama, Graha Ilmu. Yogyakarta.

Lovelock \& Wright. 2012. "Principle of Services Marketing And Management", Prentice Hall Inc. Upper Saddle River, New Jersey, USA,. 
Martono, Nanang. 2010. "Metode Penelitian Kuantitatif: Analisis Isi dan Analisis Data Sekunder", Edisi Revisi 2, Penerbit Raja Grafindo Persada. Jakarta.

Morissan, "Periklanan: Komunikasi Pemasaran Terpadu”. 2010. Penerbit Kencana Prenadamedia Group. Jakarta,.

Naresh, K, Malhotra. 2010. "Riset Pemasaran Pendekatan Terapan", Edisi Keempat Jilid 2, PT Indeks. Jakarta.

Porter, Michael E. 2007. "Strategi Bersaing (Competitive Strategy)", Penerbit Kharisma Publishing Group. Tangerang.

Pratisto, Arief. 2004. "Cara mudah mengatasi masalah Statistik dan Rancangan Percobaan dengan SPSS 12", PT Elex Media Komputindo. Jakarta.

Raco, J. R. 2010. "Metode Penelitian Kualitatif: jenis, karakteristik, dan keunggulannya", Penerbit Grasindo. Jakarta.

Saladin, H. Djaslim. 2003. "Intisari Pemasaran dan Unsur-Unsur Pemasaran” Edisi Ketiga, Penerbit Indah Karya. Bandung.

Schiffman, Leon G dan Leslie Lazar Kanuk. 2008. "Perilaku Konsumen", Edisi Ketujuh, Penerbit PT Indeks Puri Media Kembangan. Jakarta.

Sri Wahyudi, Agustinus. 2013. "Manajemen Strategik: pengantar proses berpikir strategik", Penerbit Binarupa Aksara. Jakarta.

Stanton, William J. 2000. "Prinsip Pemasaran", Jilid 1, Penerbit Erlangga. Jakarta.

Sugiyono. 2012. "Metode Penelitian Bisnis", Penerbit Alfabeta. Bandung.

Sudjana. 2005. "Metoda Statistika", Edisi 6, Penerbit PT Trasito. Bandung.

Supranto, J. 2012. "Metode Riset", Cetakan 2, Penerbit Rineka Cipta. Jakarta.

Swastha, Bashu dan T. Handoko. 2005 "Manajemen Pemasaran Moderen", BPFE. Yogyakarta.

Swastha, Basu dan Irawan. 2003 "Manajemen Pemasaran Modern, Penerbit Liberty. Yogyakarta.
Tjiptono, Fandy. 2008 "Strategi Pemasaran", Edisi Ketiga, Penerbit CV Andi Offset. Yogyakarta.

American Marketing Association, "About AMA: Definition of Marketing," <https:// www.ama.org/AboutAMA/Pages/Definition-of-Marketing.aspx $>$, Diakses tanggal 14 Februari 2018.

https://id.wikipedia.org/wiki/Pemasaran. Diakses tanggal 14 Februari 2018.

https://id.wikipedia.org/wiki/Belanja_daring, Diakses tanggal 14 Februari 2018.

https://lenterakecil.com/belanja-online-belanja-daring/, Diakses tanggal 14 Februari 2018.

http://republika.co.id/berita/ekonomi/makro/18/02/17/p496m6384-survei-masyarakat-lebih-suka-belanja-daring-keperluanimlek, Diakses tanggal 14 Februari 2018. 